\title{
重症脳損傷患者における近赤外線分光分析装置 $\left(\mathrm{NIRO}-300^{\circledR}\right)$ を 用いた脳酸素代謝障害の評価
}

\author{
堀口崇 ${ }^{1}$ 斎藤 良一 ${ }^{2}$ 各務 宏 $^{3}$ 山本紳一郎 1 \\ 菊野 隆明1 中村 芳樹2 市来㟝 潔1
}

\begin{abstract}
要旨 近赤外線分光分析装置NIRO-300 ${ }^{\circledR}$ を用いて救命救急センターに搬入された，重症脳損傷患 者に打ける酸素代謝障害のモニタリングを行った。対象は，救命救急センターに搬送された後 NIRO- $300{ }^{\circledR}$ を装着された患者のうち，両側曈孔が散大し，意識レベルが Japan Coma Scale で 300 と なった 28 例（男性 18 例，女性 10 例，平均年齢 55.9 歳）で，本装置により測定が可能となった総へ モグロビン濃度に対する酸素化へモグロビン濃度の割合（TOI）を上腕部抢よび前額部において測 定し，得られた值をTOI-A（上腕），TOI-B（前額部=脳）として，健常人の同部位から得られた 值と比較検討した。また，各種へモグロビン濃度変化および，ベッドサイドでモニタリング可能 なパラメータとTOIの変動を比較し，考察を行った。健常成人においてはTOI-BがTOI-Aよりも 高值になる傾向が認められ，一方，今回対象とした種々の重症脳損傷が生じると TOI-Bが減少し， TOI-Aよりも低值になることが明らかとなった。また，心肺機能停止蘇生後脳症の症例において， 心拍再開後の TOI-B はTOI-A よりも激しく変動していた。この変化は, 蘇生後完全社会復帰し得 た例では認められなかった。また，各種へモグロビン濃度変化あるいは他のモニタリング可能な 指標と比較対応させた結果，重症脳損傷患者の頭蓋内における酸素代謝障害を鋭敏に捉えている ことが明らかとなった。以上より，損傷脳における酸素運搬量と消費量のバランスの破綻が， TOI-B の減少となって現れることが推察された。NIRO-300 ${ }^{\circledR}$ を用いてTOI-B と TOI-A を相対的に 比較すること，各種へモグロビン濃度変化あるいは他のモニタリング可能な指標と比較対応させ ることで, 非侵襲的かつ簡便に, 脳酸素代謝障害の把握がベッドサイドで行い得る可能性が示唆 された。
\end{abstract}

（日救急医会誌 $2001 ； 12 ： 1-10$ )

キーワード：近赤外線分光分析装置，酸素代謝，重症脳損傷

はじめに

近赤外線は組織に対する透過性が高く，非侵襲的 に，連続かつリアルタイムに生体深部の情報を捉え ることができる”。Jöbsisがこの性質を利用し脳にお

Assessment of oxygen metabolism derangement in patients with severe brain damage using near-infrared spectroscopy (NIRO$300^{\circledR)}$

' 国立病院東京医療センター救命救急センター

2 同 脳神経外科 ${ }^{3}$ 済生会宇都宮病院脳神経外科

著者連絡先：テ152-8902 目黒区東が丘 2-5-1

原稿受理日：2000年 5 月 15 日 (00-034)
ける酸素モニタリングを行って以来，複数の装置が 開発されてきた 2.3)。浜松ホトニクス社製 NIRO-300 ${ }^{\circledR}$ は，体表上からプローべを装着するだけで，modified Beer-Lambert 法および空間分解分光法を用いて, 異なる二部位における, 酸素化へモグロビン濃度変 化, 還元へモグロビン濃度変化, 総へモグロビン濃 度変化，酸化-還元チトクロームオキシダーゼ濃度差 変化に加え, 総へモグロビン濃度に対する酸素化へ モグロビン濃度の割合（tissue oxygenation index, 以 下 TOI と略す）の測定が可能であり，照射点と受光 点の間隔を長く $(5 \mathrm{~cm}$ 程度 $) し$, 検出領域を短く狭 
く $(8 \times 8 \mathrm{~mm})$ し，センサーの数を増やす（3個） ことにより，確実な測定と信頼性の高い結果を実現 した装置である。しかしながら，本装置で得られた 值を直接検証する方法がないために，データーの絶 対值の解釈に関しての評価は，未だ確立されていな いのが現状である ${ }^{4,5)}$ 。

今回われわれは本装置を用いて, 救命救急セン夕 一に搬送された重症脳損傷患者の脳酸素代謝障害の 評価を行い, TOI值の臨床的意義と解釈について検 討した。また，頭蓋内に生じた脳酸素代謝異常をり アルタイムにモニタリングし得た症例を経験した。 ここにあわせて報告する。

\section{対象と方法}

平成 11 年 1 月より平成 12 年 4 月までに，国立病院 東京医療センター救命救急センターに搬送された後 NIRO-300 ${ }^{\circledR}$ 装着された患者のうち，両側瞳孔が散 大し，意識レベルがJapan Coma Scale（以下 JCS と 略す）で300 となった28例（男性 18例，女性 10例， 平均年齢 55.9 歳）を対象とした。疾患の内訳は，く も膜下出血（以下 SAH と略す）14例, 脳梗塞 2 例, 頭部外傷（びまん性損傷）4例，心肺機能停止（以 下 CPA と略す）4例，CPA蘇生後脳症4例であった。 なお，CPAの4例を除いた 24 症例における動脈血酸 素飽和度は全例 $98 \%$ 以上であった。これらの患者の 前額部および，上腕部に測定用プローベを装着し， 酸素化へモグロビン濃度変化，還元へモグロビン濃 度変化, 総へモグロビン濃度変化, TOI 連続モニ タリングした。また，TOI值の臨床的意義を検討す る目的で，上腕で得られたTOI值（以下 TOI-A と略 す), 前額部で得られた TOI值（以下 TOI-B と略す）, TOI-A から TOI-B を減じた值（以下 d-TOI と略す） を，同様の方法で健常成人 5 名から得られた值と比 較検討した。なお，測定値はNIRO- $300^{\circledR}$ を装着した 後，最初に瞳孔の散大および意識レベルがJCSで 300であることを確認し得た時点における TOIの值 を採用した。検定はKruskal-Wallis 検定を行い，p $<$ 0.05 を統計学的有意差とした。

\section{結果}

Table 1 に健常成人 5 名から得られたTOI の值を, Table 2 に今回対象とした 28 名から得られた值を示 す。これらのうち脳梗塞の2例を除いた26例を疾患 ごとに分類し，平均值と標準偏差をグラフで表した ものを Fig. 1，Kruskal-Wallis の検定を行った結果を Table 3 に示した。TOI-A, TOI-B, d-TOI ともに, p值 は 0.05 以下であり，5群間に有意な差が認められた。 順位情報を見てみると，TOI-Aでは，CPAの平均順 位が他の4群より低く，一方で，結果は示していな いが, CPAを除く4群間で同様の検定を行ったとこ ろ有意差を認めなかった。TOI-Bでは，CPAの平均 順位が他の 4 群より低く，正常群が最も高かった。 d-TOIではFig. 1からも明らかなように, 正常群が最 も低く, CPA蘇生後脳症が最も高かった。次に代表 的な症例の経時変化を示す。

症例 2 : 心肺機能停止状態で搬送された50歳の男 性。

来院時既に意識レベルはJCS で 300 ，両側の瞳孔 が散大していた。直ちに心肺蘇生術を行いながら，

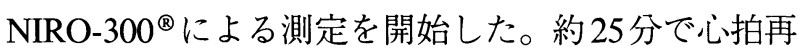
開が得られた。心拍再開直後は平均血圧 $140 \mathrm{mmHg}$ であったが，その後徐々に血圧が低下し，この時点 で測定を中止した。来院から4時間後に永眠された。

Fig. 2 にTOI-A，Bおよび前額部より得られた酸素化 ヘモグロビン $(\mathrm{O}-\mathrm{Hb})$, 還元へモグロビン (D-Hb), 総へモグロビン（T-Hb）濃度変化の経時的記録を示 した。プローべ装着の時点では，TOI-Aが40\%， TOI-Bが 28\%であり，TOI-Aが12\%高值を示してい た。心拍再開までは，この差はほぼ一定に保たれて いたが，自己心拍再開と共にTOI-A，B両者の増加 を認めた。血圧の低下にも関わらずTOI-Aにおいて はその後も高值が維持されたが，TOI-Bにおいては 再び減少が認められ，その後 $27 \%$ から $52 \%$ までを激 しく変動した。同時に測定されたへモグロビン濃度 変化では，還元へモグロビン濃度は，測定開始直後 
Table 1. Summary of 5 healthy subjects.

\begin{tabular}{lcccc}
\hline No. & Age/Sex & TOI-A & TOI-B & d-TOI \\
\hline 1 & $30 / \mathrm{M}$ & 67 & 80 & -13 \\
2 & $42 / \mathrm{M}$ & 73 & 65 & 8 \\
3 & $25 / \mathrm{F}$ & 68 & 70 & -2 \\
4 & $27 / \mathrm{F}$ & 67 & 82 & -15 \\
5 & $36 / \mathrm{M}$ & 72 & 80 & -8 \\
\hline Mean & 32 & 69.4 & 75.4 & -6 \\
\hline SD & 6.964194139 & 2.880972058 & 7.469939759 & 9.300537619 \\
\hline
\end{tabular}

Except for 1 case, TOI-B is higher than TOI-A.

TOI-A = tissue oxygenation index measured at arm ; TOI-B $=$ tissue oxygenation index measured at forehead (brain) ; d-TOI = difference between TOI-A and TOI-B

Table 2. Summary of 28 patients with severe brain damage.

\begin{tabular}{|c|c|c|c|c|c|}
\hline No. & Age/Sex & Diagnosis & TOI-A & TOI-B & d-TOI \\
\hline 1 & $56 / \mathrm{F}$ & CPA & 22 & 18 & 4 \\
\hline 2 & $50 / \mathrm{M}$ & CPA & 40 & 28 & 12 \\
\hline 3 & $48 / \mathrm{M}$ & CPA & 39 & 24 & 15 \\
\hline 4 & $78 / \mathrm{M}$ & CPA & 36 & 23 & 13 \\
\hline 5 & $4 / \mathrm{F}$ & trauma & 62 & 42 & 20 \\
\hline 6 & $24 / \mathrm{M}$ & trauma & 76 & 55 & 21 \\
\hline 7 & $21 / \mathrm{M}$ & trauma & 71 & 56 & 14 \\
\hline 8 & $33 / \mathrm{M}$ & trauma & 68 & 54 & 14 \\
\hline 9 & $51 / \mathrm{F}$ & $\mathrm{SAH}$ & 70 & 45 & 25 \\
\hline 10 & $84 / \mathrm{M}$ & $\mathrm{SAH}$ & 65 & 39 & 26 \\
\hline 11 & $45 / \mathrm{M}$ & SAH & 69 & 55 & 14 \\
\hline 12 & $64 / F$ & SAH & 75 & 68 & 7 \\
\hline 13 & $84 / F$ & SAH & 67 & 53 & 14 \\
\hline 14 & $57 / F$ & SAH & 63 & 60 & 3 \\
\hline 15 & $69 / F$ & SAH & 70 & 65 & 5 \\
\hline 16 & $51 / \mathrm{M}$ & SAH & 71 & 58 & 13 \\
\hline 17 & $55 / \mathrm{M}$ & SAH & 73 & 55 & 18 \\
\hline 18 & $57 / \mathrm{M}$ & $\mathrm{SAH}$ & 67 & 55 & 12 \\
\hline 19 & $74 / \mathrm{M}$ & SAH & 64 & 53 & 11 \\
\hline 20 & $51 / \mathrm{M}$ & SAH & 69 & 56 & 13 \\
\hline 21 & $73 / \mathrm{M}$ & $\mathrm{SAH}$ & 71 & 59 & 12 \\
\hline 22 & $67 / M$ & SAH & 69 & 58 & 11 \\
\hline 23 & $77 / \mathrm{F}$ & post-CPA & 67 & 42 & 25 \\
\hline 24 & $68 / \mathrm{F}$ & post-CPA & 69 & 44 & 25 \\
\hline 25 & $63 / \mathrm{M}$ & post-CPA & 70 & 44 & 26 \\
\hline 26 & $57 / \mathrm{F}$ & post-CPA & 75 & 55 & 20 \\
\hline 27 & $38 / \mathrm{M}$ & infarction(ICA occlusion) & 70 & 59 & 11 \\
\hline 28 & $67 / \mathrm{M}$ & infarction(BA occlusion) & 74 & 76 & -2 \\
\hline Mean & 55.92857 & & 64.35714286 & 49.96428571 & 14.35714286 \\
\hline SD & 19.12905 & & 13.26709738 & 13.75037277 & 7.288825977 \\
\hline
\end{tabular}

Except for 1 case, TOI-B is lower than TOI-A. 

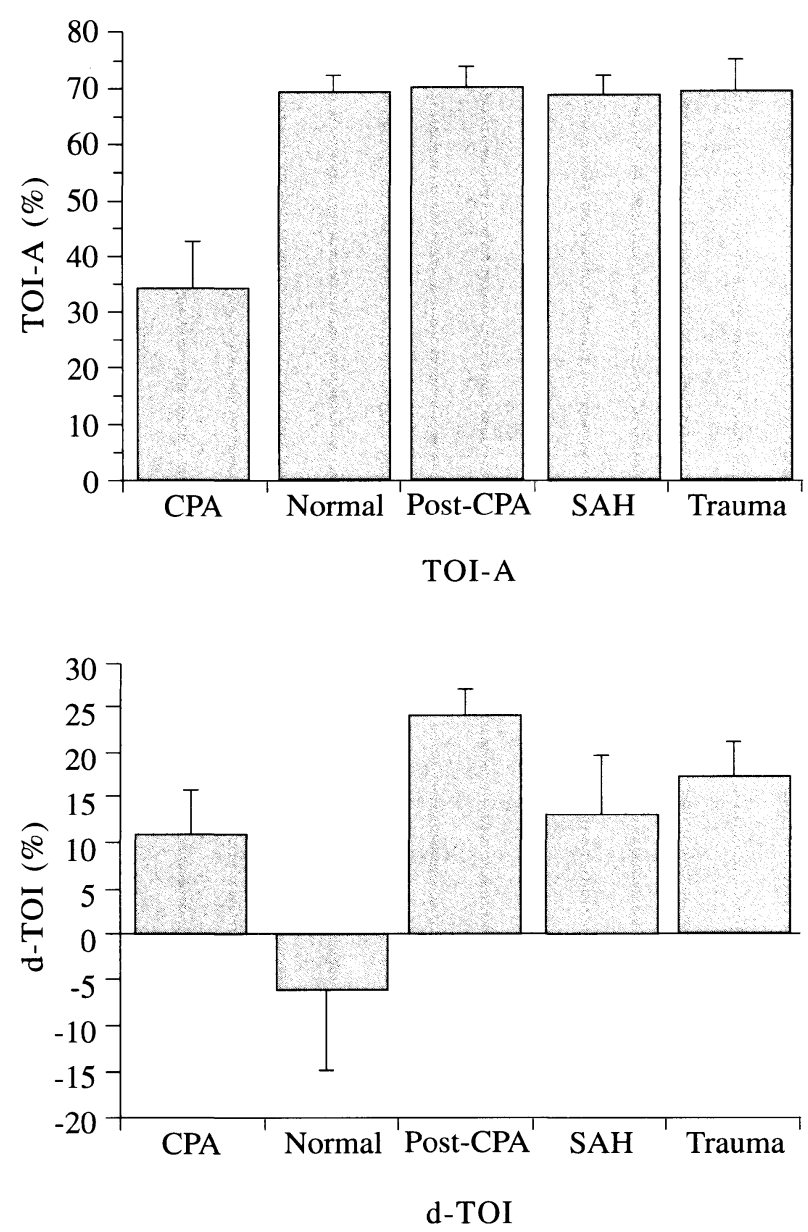

よりほぼ変化を示していない。一方，酸素化へモグ ロビン濃度と総へモグロビン濃度は，共に心拍再開 後急激に増加し，150分後に突然両者共に減少した。 測定は, この後ベッド移動のため, 中止となった。

症例 25 : 胸痛を主訴に救急搬送され，急性心筋 梗塞と診断された 63 歳の男性。

経皮経管的冠血管形成術施行中に心室細動とな $り$, 合計 10 回の電気的除細動を行い, 心拍再開が得 られたが，救命救急センター帰室時は，意識レベル はJCSで 300，両側の瞳孔は散大していた。直ちに NIRO- $300^{\circledR}$ による測定を開始した。帰室から 7 時間 後に患者の意識はJCSで 100 まで改善し，12 時間後 には，指示動作が行えるまでに回復，その後明らか な神経脱落症状を認めない状態で独歩退院となっ た。Fig. 3 にTOI-A，Bの経時的変化を示した。プロ 一べ装着の時点では，TOI-A が70\%，TOI-Bが $44 \%$

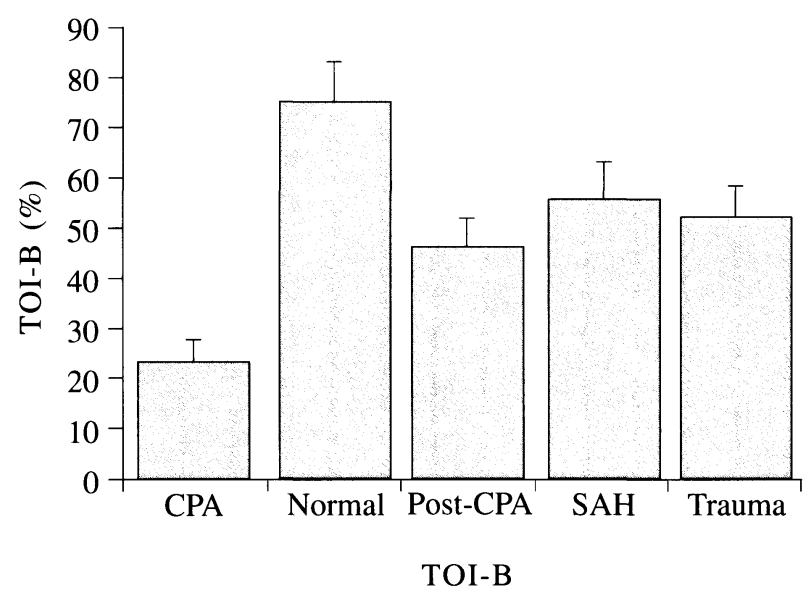

Fig. 1. Results of TOI-A,TOI-B, and d-TOI. Data is presented as mean $\pm \mathrm{SD}$.

であり，心拍再開後であっても TOI-Aが26\%高值を 示していた。しかしながら，時間の経過とともに TOI-B が改善し，帰室後 7 時間で $57 \% ， 11$ 時間後 TOI-Aの值を上回り，12 時間後には $73 \%$ ま゙回復し た。

症例 27 : 左半身麻瘴を主訴に一般病棟に入院後, 意識障害が増悪し院内転入となった 38 歳の男性。

搬入時意識レベルはJCSで 300 ，両側の瞳孔は散 大していた。CT上は広範な右大脳半球の脳梗塞を 認めた。直ちに, マンニトールの急速静注と，体温

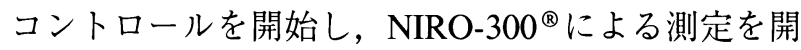
始した。なお，本症例においては，左の前額部にプ ローべを装着した。Fig. 4 にTOI-A，B および頭蓋内 圧 $(\mathrm{ICP})$, 平均動脈圧 $(\mathrm{MBP})$, 脳灌流圧 $(\mathrm{CPP})$ の経時的変化を示した。プローべ装着の時点では, TOI-Aが70\%，TOI-Bが59\%であったが，その後一 時的に脳温の低下と共に脳圧の低下を認め，それに 伴いTOI-Bも66\%まで改善した。その後の TOI-B は, 脳圧㧍よび脳灌流圧の変化と連動した変化を呈し, 脳圧の制御が不可能となり, 脳灌流圧が $70 \mathrm{mmHg}$ を 下回ると同時に急激に低下した。 
Table 3. Results of Kruskal-Wallis analysis.

\begin{tabular}{|c|c|c|c|c|c|c|}
\hline \multirow[b]{2}{*}{ Rank } & \multicolumn{2}{|c|}{ TOI-A } & \multicolumn{2}{|c|}{ TOI-B } & \multicolumn{2}{|c|}{ d-TOI } \\
\hline & Sum & Mean & Sum & Mean & Sum & Mean \\
\hline CPA & 10 & 2.5 & 10 & 2.5 & 57 & 14.25 \\
\hline Normal & 90 & 18 & 143.5 & 28.7 & 19 & 3.8 \\
\hline post-CPA & 79 & 19.75 & 39.5 & 9.875 & 111 & 27.75 \\
\hline SAH & 242.5 & 17.321 & 248 & 17.714 & 219.5 & 15.679 \\
\hline Trauma & 74.5 & 18.625 & 55 & 13.75 & 89.5 & 22.375 \\
\hline Tied p-value & 0.0334 & & 0.0003 & & 0.0013 & \\
\hline
\end{tabular}

$\mathrm{CPA}=$ Cardiopulmonary arrest $; \mathrm{SAH}=$ Subarachnoid hemorrhage

Tied p-valuc $<0.05$ is statistically significant.
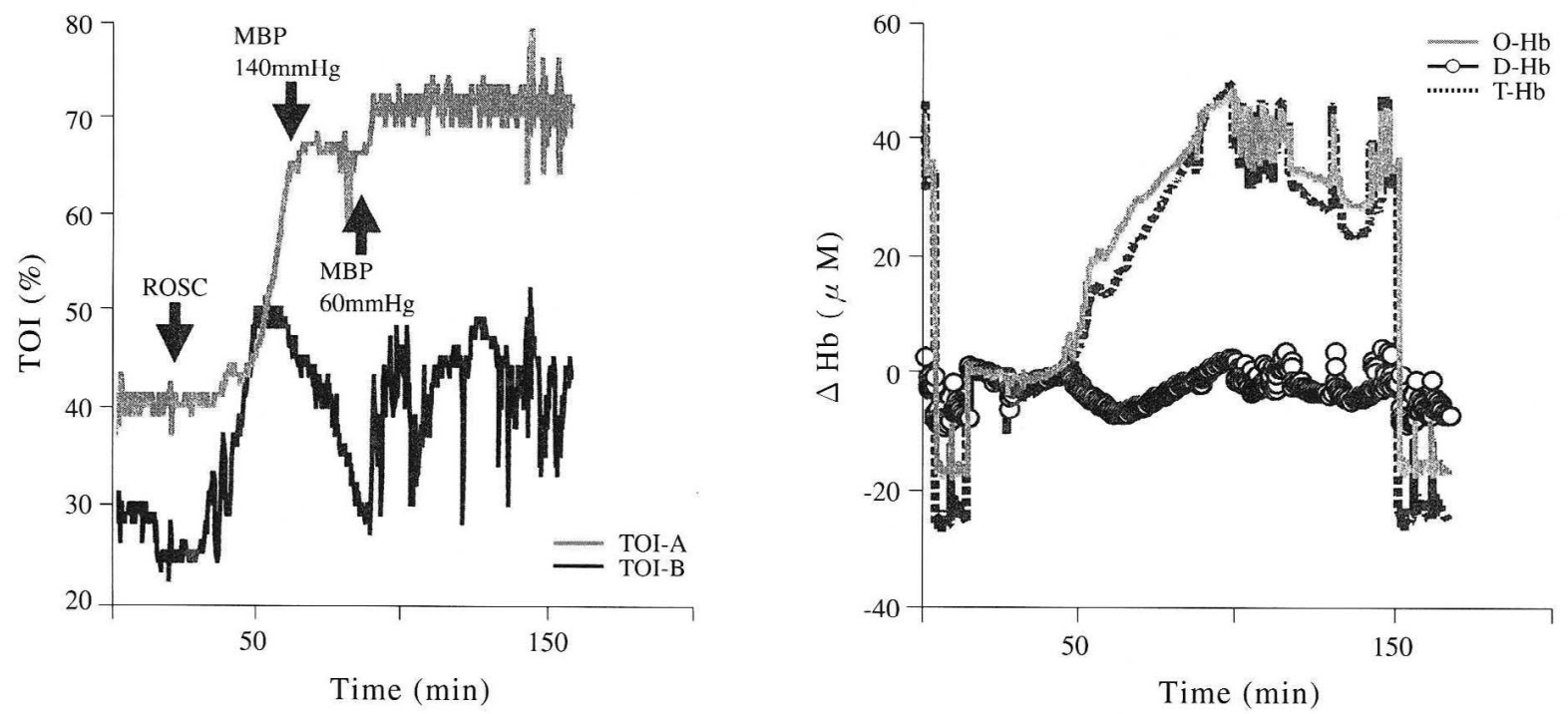

Fig. 2. Time course of change in TOI-A and TOI-B in Casc 2.

The sharp fluctuation of TOI-B is recorded after the return of spontaneous circulation. Increments in $\mathrm{O}-\mathrm{Hb}$ and $\mathrm{T}-\mathrm{Hb}$ concentration are recorded in the reperfusion phase. Sudden drop of concentration in $\mathrm{O}-\mathrm{Hb}$ and $\mathrm{T}-\mathrm{Hb}$ occurs prior to decrease of TOI-B.

$\mathrm{O}-\mathrm{Hb}=$ oxidative hemoglobin ; $\mathrm{D}-\mathrm{Hb}=$ deoxidative hemoglobin ; $\mathrm{T}-\mathrm{Hb}=$ total hemoglobin ; $\mathrm{ROSC}=$ return of spontaneous circulation $; \mathrm{MBP}=$ mean blood pressure

\section{考察}

重症脳損傷患者に掞ける脳循環代謝モニターとし ては，内頸静脈酸素飽和度が普及しているが，これ は血液を介した間接的な情報であり，生体内へカテ ーテルを挿入するという侵襲を伴う方法である6.7\%。 近赤外線は，組織透過性に優れており ${ }^{1,8)}$, この性質 を利用した近赤外線分光分析装置は，頭蓋骨を通し て脳内の情報を非侵襲的にリアルタイムに連続的に
測定することが可能な装置である6。近年，さまざ まな装置が開発され ${ }^{3)}$, 臨床応用例も報告されてい る ${ }^{9-16)}$ 。近赤外線分光分析装置を用いた従来の報告は， 酸素化および還元へモグロビンの濃度変化を経時的 に測定する相対的評価が主体であった ${ }^{3.5) 。 ~}$

今回われわれが用いた NIRO-300 ${ }^{\circledR}$ は, 従来の測定 項目に加え, 絶対的な指標である TOIの測定を可能 にした点が注目されているが，1998年に開発された まだ歴史が浅い装置であるため, その值の評価は未 


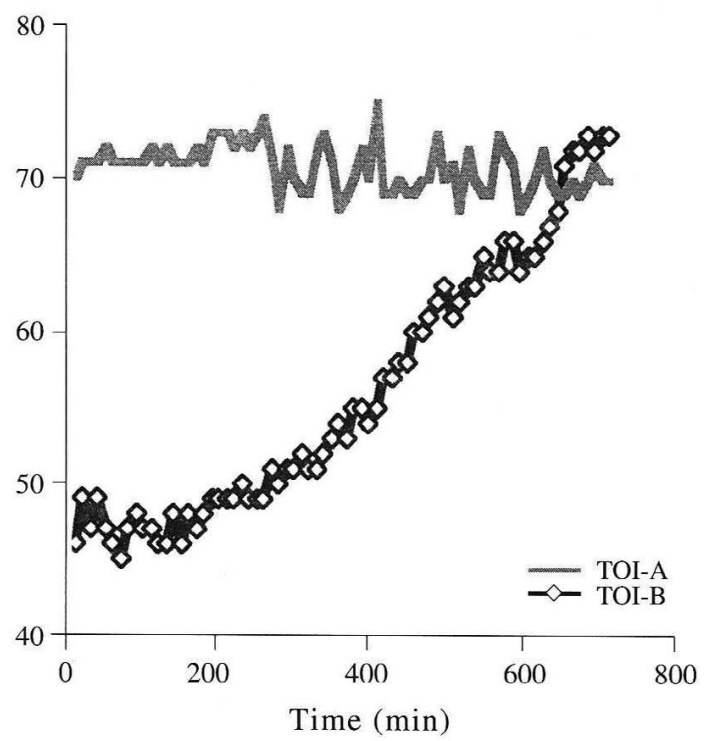

Fig. 3. Time course of change in TOI-A and TOI-B in Case 25. The gradual recovery of TOI-B without widely variation is recorded after the return of spontaneous circulation.

だ十分に検討されていない4)。そこでわれわれは， まず測定されたTOI値についての考察を行った。は じめに，值の再現性について検討した。聅患毎に TOI-Aを比較した結果，全身の循環不全状態である $\mathrm{CPA}$ を除く4群間で有意差を認めなかったことから， 少なくとも安定した循環状態が維持されている環境 下で測定されたTOI值は再現性を持った，信頼し得 るデーターであると考えられた。次にTOI-B と TOI$\mathrm{A}$ の比較を行い，その臨床的意義について検討した。 健常成人においてはTOI-BがTOI-Aよりも高值にな る傾向が認められ，一方，今回対象とした種々の重 症脳損傷が生じると，脳幹梗塞を除いた全例でTOIBが減少し，TOI-Aよりも低值になることが，d-TOI の検討からも明らかとなった。正常時においては， 毛細血管に存在する動脈血と静脈血の割合から，局 所の酸素飽和度は,

$\left(\mathrm{SaO}_{2} \times 0.25\right)+\left(\mathrm{SvO}_{2} \times 0.75\right)$ で表すことが可 能であり ${ }^{3)}, \mathrm{SaO}_{2}$ が一定であると仮定すれば，主とし て静脈血の酸素飽和度を表していると考えられる17)。 一般に，脳酸素摂取率は他臟器より高いため，内頸 静脈酸素飽和度の正常值は混合静脈血酸素飽和度の
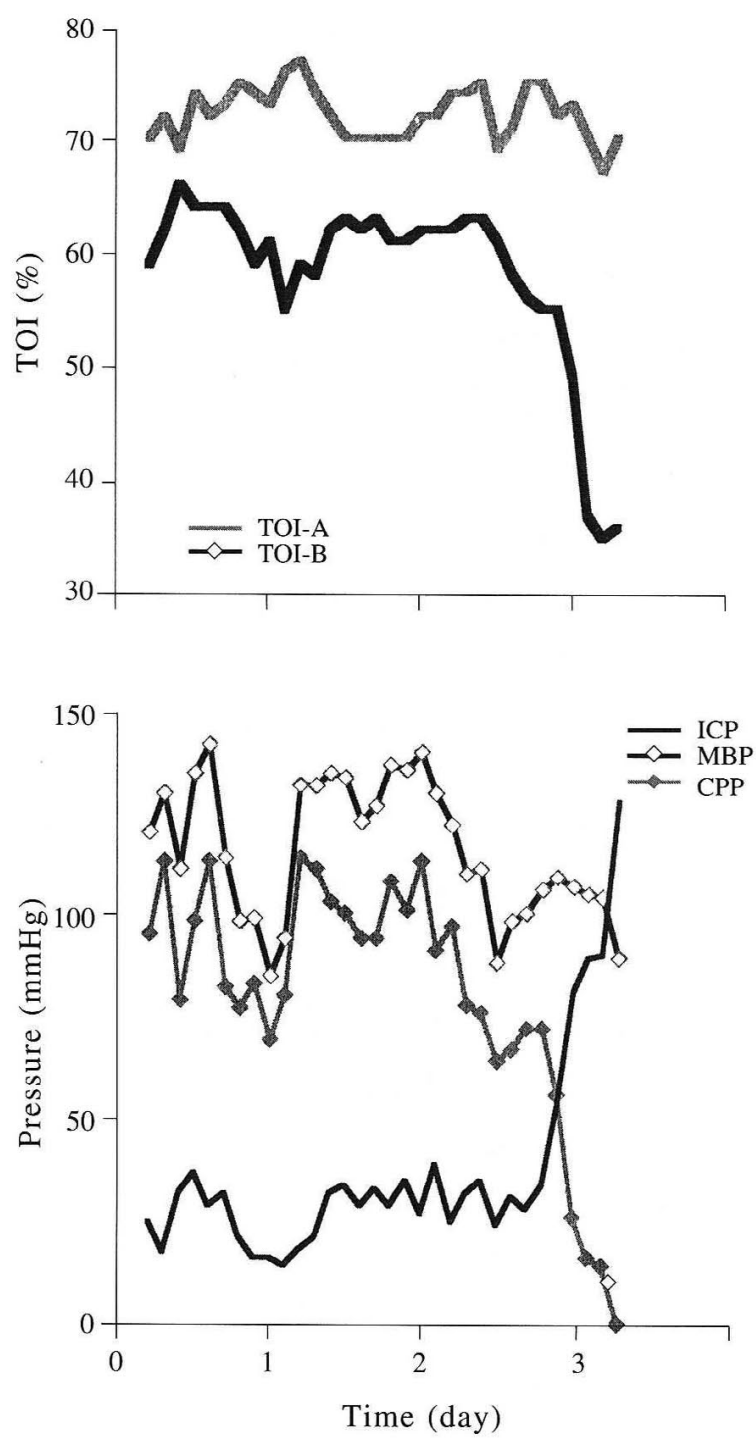

Fig. 4. Time course of change in TOI-A and TOI-B combined with simultaneously recorded change of intracranial pressure, mean arterial blood pressure, and cerebral perfusion pressure in Case 27.

A definite correlation between cerebral perfusion pressure and TOI-B is recorded. TOI-B is not reduced until cerebral perfusion pressure falls below $70 \mathrm{mmHg}$.

$\mathrm{ICP}=$ intracranial pressure ; $\mathrm{MBP}=$ mean arterial blood pressure ; $\mathrm{CPP}=$ cerebral perfusion pressure

正常値より低いとされており》，これはわれわれの 結果と相反する。この理由としては，測定の対象と している範囲が異なることと, 測定原理が異なるこ とが挙げられると考えられる。測定の対象範囲とし てはNIRO-300®では，照射・検出点間距離を $4 \mathrm{~cm}$ と したときに脳表から $0.9 \mathrm{~cm}$ 深部の局所血流との相関 
が高いとされている ${ }^{18)}$ 。しかし，内頸静脈酸素飽和 度は脳全体の循環代謝の結果を反映する值であり， 混合静脈血と TOI-Aに関しても同様の関係があては まる。したがって，TOI と静脈血酸素飽和度は，同 一の変化を示さない可能性があると考えられる。一 方，測定原理に関してはTOIは，近赤外線が組織内 をある距離進み, 散乱および吸収された結果, 光量 が減弱することから, 検出光量の距離に対する変化 率を基に計算されている。ここで，頭蓋骨を含む頭 部皮下組織と筋肉が主体である上腕皮下組織におけ る散乱係数および，吸収係数は異なるため，各部位 で得られた值は，異なる計算式から導かれた解であ ると考えられる。このことは，異なる組織における TOIの絶対值を静脈血酸素飽和度のように同一環境 における数値として絶対的に比較してはならないこ とを示している。しかしながら，正常健人において 得られた值には，ばらつきがあり，また症例 12 あ るいは15のように，TOI-Bだけを観察していたので は，正常健人との違いが明らかではない場合もある。 これらの症例において正常健人と異なっているの は，TOI-AがTOI-Bを上回っていることのみであっ た。したがって，われわれは一貫して同一部位で測 定される限り，本装置で得られたTOI-A と TOI-Bを 相対的に比較することが臨床的に有用ではないかと 考えている。

一方，今回対象としたような重症損傷脳において 認められたTOI-Bの低下は，脳局所における総へモ グロビン濃度に対する酸素化へモグロビン濃度の占 める割合の減少を示している。ここで，総へモグロ ビンの濃度変化は, 脳血液量を反映している ${ }^{19)}$ ので, TOI-B の変化は脳血液量の変化または脳酸素摂取率 の変化によって決定されると考えられる。重症脳損 傷の結果, 脳における酸素運搬量と消費量のバラン スが破綻し，TOI-Bの減少となって現れると考えら れた。この解釈は, 内頸静脈酸素飽和度が变化する 機序と共通している ${ }^{3,7)}$ 。しかしながら，病的な状態 においては，局所における毛細血管に存在する動脈 血と静脈血の割合が変化することが予想される。例
えば，脳虚血後に毛細血管あるいは細静脈レベルで の白血球による塞栓形成などが指摘されている ${ }^{20)}$ 。 したがって，病的状態における TOI-Bの変化が内頸 静脈酸素飽和度と同じように低下するのかは不明で ある。今後TOI-Bの臨床的意義を明らかにするため に内頸静脈酸素飽和度との相関を検討していく必要 もあると考えられる。

今回の検討では, SAHの症例数に対し他の疾患が 少数であったため, 疾患ごとの有意な差を検討する ことはできなかった。また，CPA となった原因が全 例で診断されておらず，また個々の症例数も少ない ため，背景疾患そのものがTOIに及ぼす影響につい ても，考察できなかった。TOIを絶対值で解釈する ことが，どのような臨床的意義を持つかについては, これらの検討が必要不可欠であるが，今後のさらな る症例数の蓄積が必要であると考えられた。しかし ながら，提示した代表症例にあるように，TOI-Bの 変化を TOI-A と比較すること（Fig. 2,3）や，各種へ モグロビン変化と対応させること（Fig. 2）あるいは 他のモニタリング可能な指標と比較（Fig. 4）するこ とで，それぞれの特徵を考察することは可能であっ た。Fig. 2を見ると，心拍再開後にTOI-Aは，比較 的安定しているのに対し, TOI-Bは激しく変動して おり, 虚血再灌流後の脳内酸素代謝が体循環と比較 して不安定であることが推測される。この現象は, 脳酸素代謝が回復した症例である Fig. 3では認めら れていないことから，予後を知る因子の一つになり 得ると考えられる。また, Fig. 2におけるこの時点 でのへモグロビン濃度変化を見ると, 総へモグロビ ン濃度が酸素化へモグロビン濃度と同様の変化を示 している。すなわち, 虚血再灌流後の増加を来して おり，いわゆる postischemic hyperpefusion ${ }^{21)}$ の状態 を捉えている可能性があると考えられる。また，そ の後に生じる酸素化ならびに総へモグロビン濃度変 化の急激な低下は, postischemic delayed hypoperfusion ${ }^{22)}$ の状態を示している可能性があると考えられ る。症例 2（Fig. 2）において観察された心拍再開後 の TOI-B の上昇は, 一見, 脳酸素代謝の回復が生じ 
たように見受けられる。

しかしながら，このTOI-B 上昇の主因は，同時に 記録された還元へモグロビンの増加を伴わない，酸 素化へモグロビン濃度の上昇によるものである。も しも, 酸素代謝が回復していれば，還元へモグロビ ンの増加も観察されるはずである。心拍再開に伴い, 血液量を反映する総へモグロビン濃度が増加してい るが，それは，脳酸素代謝には関与していないもの と考えられる。したがって，自己心拍再開後のTOI$\mathrm{B}$ の上昇は，必ずしも脳酸素代謝の回復を意味して おらず，これがその後の TOI-Bの変動が激しいこと にも関与している可能性がある。このように，虚血 再灌流後の脳酸素代謝障害は TOI の変化のみではな く，ヘモグロビン濃度変化を考慮に入れることで, より正確な病態の把握が可能になると考えられた。 また, Fig. 4で示したように, TOI-Bの変化は, 平均 血圧の低下に伴う脳灌流圧の変動とよく相関してお り，脳灌流圧が $70 \mathrm{mmHg}$ を下回ると TOI-Bが減少す ることが捉えられている。本症例においては頭蓋内 圧が上昇するのは，TOI-Bの減少が生じてからさら に後の変化であり，TOI-Bが脳循環の影響を鋭敏に 受けることが示唆された。TOI-A はほぼ一定の值を 保っていることから，体循環の酸素代謝に影響が及 ばない程度の血圧の変動であっても，自動調節能が 破綻した損傷脳においては重篤な影響を及ぼすこと が，本装置の連続モニタリングで捉えられていると 考えられた。

本装置を用いた測定の欠点として，頭皮血流の contamination, 出血症例における血管外に存在する へモグロビンの影響，頭髪による影響が無視できな いため測定部位は前額部に限られる，長時間の測定 によりプローべ装着部位の局所血流が低下し紅斑に なる，などが考えられる7。近赤外線分光分析装置 を用いた報告では正常人9,12,13) あるいは頸動脈疾患 ${ }^{14)}$ など頭蓋内に器質的な疾患のない場合の有用性につ いてはほほ見解が一致しているのに対し，頭部外傷 あるいは脳血管障害などの症例に対する有用性は未 だに議論の対象である 10,11,15,16)。われわれは，SAH症
例の脳血管攣縮の時期に，本装置を用いた連続モ二 タリングで，TOI-Bが鋭敏に低下していく例を経験 しているが (今回の対象には含まれていない)，一 方で今回の検討のなかでは，症例 12 と症例 15 は両 者ともSAHの症例であるが, TOI-Bはプローべ装着 時より65\%を上回っており，その後もまったく変動 がなく，60\%から 70\%を示していた。Table 3で示し たように，TOI-B 值の平均順位が，SAHと外傷にお いてCPAあるいは蘇生後脳症よりも高いことは，血 管外のへモグロビンの影響を受けている可能性も考 えられる。出血症例において得られた結果の解釈に は，今後さらなる検討が必要であると考えられる。 一方，最近本装置により，組織におけるへモグロビ ン濃度の相対值を示す数字である組織へモグロビン 指標（tissue hemoglobin index：THI）の測定が可能 となった。このことは脳血液量を反映するパラメー 夕 ${ }^{19)}$ が増加したことを意味しており, 今後の応用が 期待されている。

以上，重症脳損傷患者における近赤外線分光分析 装置 $\left(\mathrm{NIRO}-300^{\circledR}\right)$ を用いた脳酸素代謝障害の評価 について，われわれの得た結果とその解釈について 述べた。NIRO- $300^{\circledR}$ の最大の利点は，簡便性抢よび 非侵襲性にあると思われる。現段階においては，未 だ症例数が少なく十分な評価はできていないと考え られるが，今回の検討の結果，NIRO-300 ${ }^{\circledR}$ 用いて 非侵襲的かつ簡便に, 脳酸素代謝障害の把握がベッ ドサイドで行い得る可能性が示唆された。

本論文の要旨は 1999 年 11 月, 第 27 回日本救急医学会 総会（東京）にて発表した。

\section{文献}

1) Delpy DT, Cope M, van der Zee P, et al : Estimation of optical pathlength through tissue from direct time of flight measurement. Phys Med Biol $1988 ; 33$ : 1433-42.

2) Jobsis FF : Noninvasive, infrared monitoring of cerebral and myocardial oxygen sufficiency and circulatory parameters. Sceience $1977 ; 198: 1264-7$.

3）横田裕之, 畧本恭子, 黒川顕: 脳酸素モニタ一. 救急 
医 $1999 ; 23: 221-6$.

4) Suzuki S, Takasaki S, Ozaki T, et al : Tissue Oxygenation Monitor using NIR Spatialyy Resolved Spectroscopy. Proc SPIE $1999 ； 3597 ： 582-92$.

5）各務宏, 斎藤良一, 新美牧, 他：救命救急センターに おける頭蓋内酸素モニタリング - NIRO300の使用経 験一。日救急医会関東誌 $1999 ； 20 ： 102-3$.

6）中村直人：近赤外分光装置とその応用. 日生理人類会 誌 $1996 ; 1: 47-50$.

7）櫛英彦, 清島尚, 斎藤豪 : 脳循環代謝モニター；最近 の知見(2). 救急医 $1998 ; 22: 917-21$.

8) Madsen PL, Secher NH : Near-Infrared oximetry of the brain. Prog Neurobiol 1999 ; 58 : 541-60.

9) Wolf $\mathrm{M}$, Weber $\mathrm{O}$, Keel $\mathrm{M}$, et al : Comparison of cerebral blood volume measured by near infrared spectroscopy and contrast enhanced magnetic resonance imaging. Adv Exp Med Biol 1999 ; 471 : 767-73.

10) Kampfl A, Pfausler B, Denchev D, et al : Near infrared spectroscopy (NIRS) in patients with severe brain injury and elevated intracranial pressure. A pilot study. Acta Neurochir (Suppl) $1997 ; 70: 112-4$.

11) Kirkpatrick PJ, Smielewski P, Czosnyka M, et al : Nearinfrared spectroscopy use in patients with head injury. J Neurosurg $1995 ; 83: 963-70$.

12) Sakatani K, Katayama Y, Yamamoto $T$, et al : Changes in cerebral blood oxygenation of the frontal lobe induced by direct electrical stimulation of thalamus and globus pallidus : a near infrared spectroscopy study. J Neurol Neurosurg Psychiatry $1999 ; 67: 769-73$.

13) Terborg C, Gora F, Weiller C, et al : Reduced vasomotor reactivity in cerebral microangiopathy : A study with near-infrared spectroscopy and transcranial doppler sonography. Stroke $2000 ; 31$ : 924-9.

14) Smielewski P, Czosnyka M, Pickard JD, et al : Assessment of cerebrovascular reactivity in patients with carotid artery disease using near-infrared spectroscopy. Acta Neurochir Suppl $1998 ； 71$ : 263-5.

15) Tateishi A, Maekawa T, Soejima $Y$, et al : Qualitative comparison of carbon dioxide-induced change in cerebral near-infrared spectroscopy versus jugular venous oxygen saturation in adults with acute brain disease. Crit Care Med $1995 ; 23: 1734-8$.

16) Lewis SB, Myburgh JA, Thornton EL, et al : Cerebal oxygenation monitoring by near-infrared spectroscopy is not clinically useful in patients with severe closed-head injury : a comparison with jugular venous bulb oximetry. Crit Care Med 1996 ； $24 ： 1334-8$.

17) Mchedlishvili $G$ : Cerebral arterial behavior providing constant cerebral blood flow, pressure, and volume. In : Bevan JA, eds. Arterial Behavior and Blood circulation in the Brain. Plenum Press, New York, 1986, pp42-95.

18) Villringer $K$, Minoshima S, Hock $C$, et al : Assessment of local brain activation. A simultaneous PET and nearinfrared spectroscopy study. Adv Exp Med Biol 1997 ; $413: 149-53$.

19）小林俊哉, 緒方博丸, 羅小星, 他: 近赤外線分析装置 （NIRモニター）からみた出血性ショックにおける高 張食塩水 $(7.5 \%)$ 投与時の脳組織酸素代謝の検討。麻 酔 $1995 ; 44 ： 244-51$.

20）岡田靖：虚血性脳疾患の病態. b. 脳虚血と細胞接着分 子. 血栓と循環 $1995 ; 3: 16-23$.

21) Hossmann KA, Lechtape-Gruter H, Hossmann V : The role of cerebral blood flow for the recovery of the brain after prolonged ischemia. J Neurol $1973 ; 204$ : 28199.

22) Suzuki R, Yamaguchi T, Klatzo I, et al : The effects of 5minute ischemia in mongolian gerbils : II. Changes of spontaneous neuronal activity in cerebral cortex and CA1 sector of hippocampus. Acta Neuropathol 1983; 60 : 217-22. 


\section{ABSTRACT \\ Assessment of Oxygen Metabolism Derangement in Patients with Severe Brain Damage Using Near-infrared Spectroscopy (NIRO-300 $\left.{ }^{\circledR}\right)$}

Takashi Horiguchi', Ryouichi Saito' ${ }^{2}$ Hiroshi $\mathrm{Kagami}^{3}$, Shinichiro Yamamoto' Takaaki Kikuno', Yoshiki Nakamura² and Kiyoshi Ichikizaki'

'National Tokyo Medical Center Critical Care Medical Center ${ }^{2}$ Department of Neurosurgery, National Tokyo Medical Center ${ }^{3}$ Department of Neurosurgery, Saiseikai Utsunomiya Hospital

To assess the derangement of oxygen metabolism in 28 patients with severe brain damage, near-infrared spectroscopy (NIRO-300 ${ }^{\circledR}$ ) was used in the intensive care unit. The consciousness in all patients scored 300 on the Japan Coma Scale (score 3 on the Glasgow Coma Scale) and bilateral pupils were dilated without light reflex. In addition to changes in oxygenated, deoxygenated, and total hemoglobin concentration, a tissue oxygenation index (TOI) -- the ratio of oxygenated to total tissue hemoglobin -- was measured at the forehead (TOI-B) and arm (TOI-A) simultaneously. Data was compared to that from 5 healthy subjects. Representative cases showed a correlation between TOI-B and the change in hemoglobin concentration or parameters monitored concurrently. In healthy subjects, TOI-B tended to be higher than TOI-A. In contrast, TOI-B of 28 patients was lower than TOI-A except for 1 with brain stem infarction. The time course of changes in TOI-A and B in transient cardiac arrest whole brain ischemia indicated that TOI-B fluctuated widely, whereas variations in TOI-A were not significant after the return of spontaneous circulation. This sharp variation was not observed in a good recovery without neurological deficit despite transient cardiac arrest. Multiple parameter recording showed a good correlation between the fluctuation in TOI-B and concentration in hemoglobin or cerebral perfusion pressure. We concluded that the breakdown of the relationship between oxygen delivery and consumption in the damaged brain reducted TOI-B. NIRO-300 ${ }^{\circledR}$ may therefore have potential for simple, noninvasive diagnostic monitoring in patients with severe brain damage.

(JJAAM $2001 ; 12: 1-10$ )

Key Words : near-infrared spectroscopy, oxygen metabolism, severe brain damage

Received for publication on May 15, 2000 (00-034) 